\title{
COMPUTED TOMOGRAPHIC APPEARANCE OF GIANT CELL REPARATIVE GRANULOMA OF A TARSAL BONE
}

\author{
Kathry L. CoOk and Ethan M. Braunstein* \\ University of Michigan Hospitals, Department of Radiology, Taubman Center 2910/0326, \\ 1500 E. Medical Center Drive, Ann Arbor, MI 48109-0326, U.S.A.
}

(Received 10 April 1987; received for publication 6 July 1987)

\begin{abstract}
A case of a rare giant cell lesion of a tarsal bone, giant cell reparative granuloma, is presented with CT correlation. CT is useful in pre-operative management both in defining the extent of involvement of adjacent structures and demonstrating soft tissue abnormality.
\end{abstract}

Giant cell reparative granuloma Giant cell lesion

\section{INTRODUCTION}

Giant cell reparative granuloma is an unusual tumor-like lesion involving facial bones or small bones of the hands and feet. Radiographic findings are not specific, and the diagnosis may be confused with that of giant cell tumor, brown tumor of hyperparathyroidism and aneurysmal bone cyst. The case described here shows the usefulness of computed tomography in defining the extent of both the lesion and the associated soft tissue mass in the tarsus.

\section{CASE REPORT}

A 33-year-old male marathon runner presented with a three month history of pain and swelling in the tarsal area of the right foot. He consulted a chiropractor, who treated the foot by manipulation. A local physician also injected the tender area with steroids, but this did not bring relief. The patient was then referred for further evaluation. Initial radiographs (Fig. 1) demonstrated a focal lytic lesion of the second cuneiform. There was no expansion of the bone and no apparent cortical destruction. Because of the history of previous injection, a presumptive diagnosis of osteomyelitis was made. Computed tomography (Fig. 2) demonstrated bone destruction confined to the second cuneiform, with disruption of the cortex laterally and a small soft tissue mass adjacent to the bone. Open biopsy showed giant cell reparative granuloma rather than osteomyelitis.

\section{DISCUSSION}

Giant cell reparative granuloma is a rare benign tumor-like condition which, although a distinct pathologic entity, is part of a spectrum of skeletal lesions containing giant cells. These lesions include giant cell reparative granuloma, aneurysmal bone cyst, giant cell tumor, nonossifying fibroma and brown tumor of hyperparathyroidism. For brown tumor, the lack of any other evidence of hyperparathyroidism and the normal texture of the bone matrix excludes the diagnosis.

Giant cell reparative granulomas were first described in the mandible and maxilla [1]. More recently, giant cell reparative granulomas were also found to occur in small tubular bones of the hands and feet as well as in the tarsal and carpal bones. In a recent series of giant cell lesions [2] there were 11 giant cell reparative granulomas; 7 occurred in men and 4 occurred in women. The average age at diagnosis was 22 years. Involvement of the tarsal and carpal bones is somewhat unusual. In the above series there are only two cases involving the tarsus in 11 cases of giant cell reparative granuloma. Giant cell reparative granulomas may also be multifocal [3].

* To whom correspondence should be addressed. 


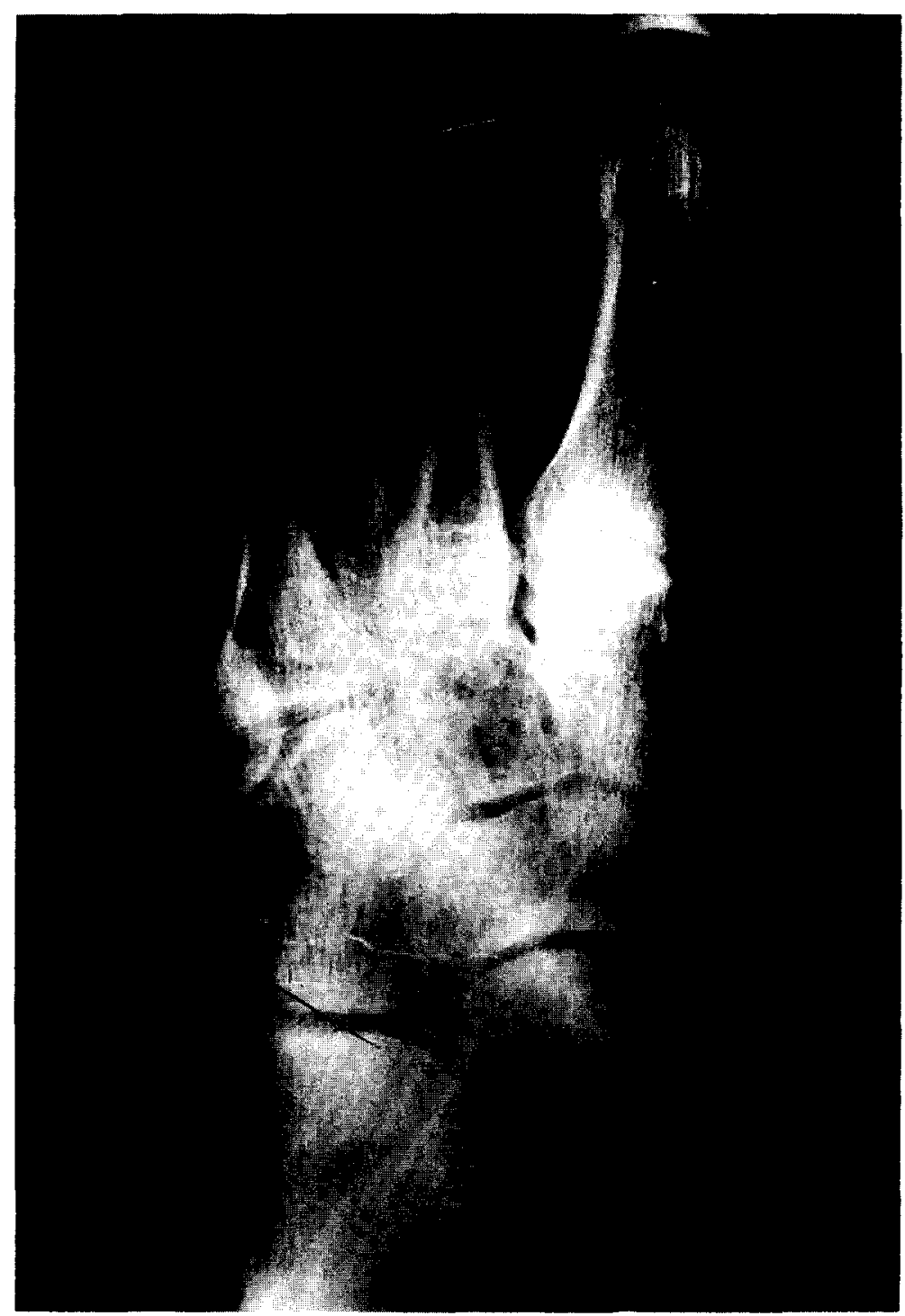

Fig. 1. Radiograph of the right foot shows a poorly defined lucent lesion of the second cuneiform with an apparent intact cortex and lack of expansion. Adjacent bones appear uninvolved and no soft tissue mass can be appreciated.

Clinically, presenting complaints include pain or swelling. Rarely, there is a history of antecedent trauma [4]. Radiologically, the features are somewhat nonspecific. The lesions usually are lytic and expansile, and they are not typically associated with large soft tissue masses. Occasionally, there may be significant cortical destruction with a large amount of soft tissue swelling [5]. As with giant cell tumors, there is no matrix calcification. Although giant cell reparative granulomas may be confused with giant cell tumors, brown tumors and other expansile slowly growing lesions, the location in the hands, feet, or facial bones may suggest the diagnosis.

Pathologically, giant cell reparative granuloma may resemble giant cell tumor in that there are multiple giant cells. However, in giant cell reparative granuloma the discrete collections of multinucleated giant cells frequently surround an area of intraosseous hemorrhage. The background matrix is largely fibrous stroma, an important differentiating feature [6]. Although the etiology of giant cell reparative granuloma is unknown, it has been suggested [1] that it may be the result of prior intraosseous hemorrhage.

Giant cell reparative granulomas do not metastasize, but they may be locally agressive. The recurrence rate approaches $50 \%$ [3]. Initially, giant cell reparative granulomas are frequently treated 


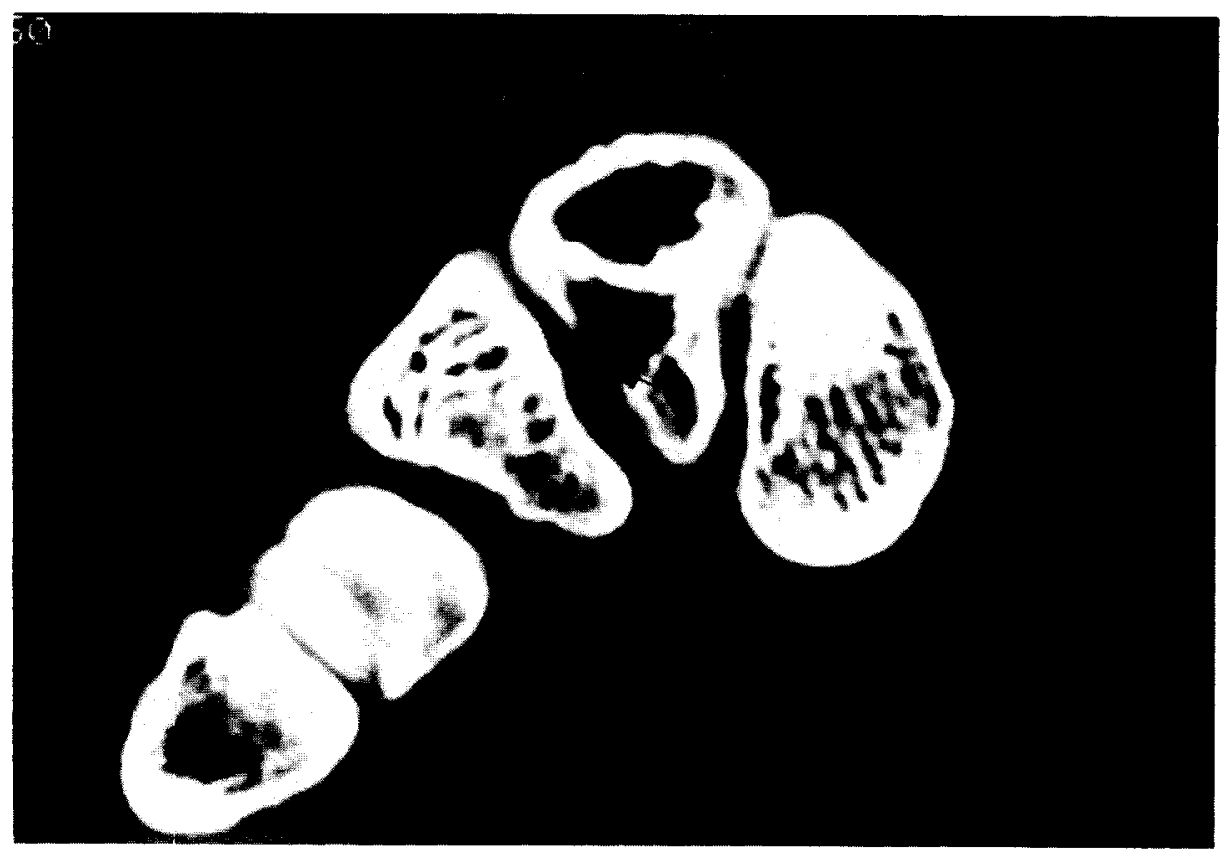

Fig. 2. Computed tomographic axial section of the right foot demonstrates focal lytic destruction of the second cuneiform with disruption of the lateral cortex (arrow) and a small soft tissue component.

with curettage and bone chip packing, but at recurrence, amputation of a digit may be considered if the initial lesion was in a small tubular bone of the hand or foot.

Computed tomography is useful in delineating the anatomic extent of these lytic lesions, particularly in such areas as the carpus and tarsus. Plain radiography may neither show the entire extent of bone destruction and soft tissue mass nor the relationships of the lesion to surrounding small bones. We suggest that computed tomography is important in preoperative planning for patients who have this rare lesion.

\section{REFERENCES}

1. H. L. Jaffe, Giant cell reparative granuloma, traumatic bone cyst and fibrous (fibro-osseous) dysplasia of the jaw bones, Oral Surg. 6, 159-175 (1953).

2. P. Picci, N. Baldini, A. Sudanese et al., Giant cell reparative granuloma and other giant cell lesions of the bones of the hands and feet, Skeletal Radiol. 15, 415-421 (1986).

3. P. Caskey, M. D. Wolf and R. E. Fechner, Multicentric giant cell reparative granuloma of the small bones of the hand, Clin. Orthop. 193, 199-205 (1985).

4. P. Jernestrom and H. H. Stark, Giant cell reaction of a metacarpal, Am. J. Clin. Pathol. 55, 77-81 (1974).

5. T. A. Glass, S. E. Millis, R. E. Fechner et al., Giant cell reparative granuloma of the hands and feet, Radiology 149, 65-68 (1983).

6. L. V. Ackerman and II. J. Spjut, Giant cell reaction. In Tumors of Bone and Cartilage. Atlas of Tumor Pathology, pp. 282-283. AFIP, Washington (1962).

About the Author-KathrYn Lisa CooK received her B.A. in Biology at Wayne State University, Detroit, Michigan in 1981 and her M.D. in 1985 from the University of Michigan. She is a second year radiology resident at the University of Michigan. Dr Cook is a member of Phi Beta Kappa, Alpha Omega Alpha and the Radiologic Society of North America.

About the Author--ETHAN M. BraunSTEIN attended Dartmouth College and he graduated from Northwestern University Medical School in 1970. Dr Braunstein is Professor of Radiology and Director of the Division of Skeletal Radiology at Indiana University Medical School. He has held prior faculty appointments at the University of Michigan and Harvard University. His research interests include radiology of carpal instability, image processing in skeletal radiology and anthropologic applications of imaging techniques. Dr Braunstein is a member of the International Skeletal Society, Association of University Radiologists, Radiologic Society of North America, American Roentgen Ray Society and American Association of Physical Anthropologists. 